\title{
A COLLECTION OF CONCERTOS BY GIUSEPPE TARTINI IN THE STAATSBIBLIOTHEK ZU BERLIN - PREUSSISCHER KULTURBESITZ
}

\author{
ADA BEATE GEHANN \\ Tübingen
}

Izvleček: $V$ središču razprave so Tartinijevi koncerti in številni seznami njegovih koncertov in sonat, ki jih danes hrani Berlinska državna knjižnica v okviru pruske kulturne dediščine, ter domneve o njihovem izvoru. Vsi koncerti (38 rokopisov) in seznami (7) so bili domnevno del zbirke še nepojasnjenega izvora. Rokopisom lahko sledimo vse od Padove, središča Tartinijevega delovanja, do Francije, a tudi Belgije $v$ 19. stoletju.

Ključne besede: koncerti 18. stoletja, zbirka iz 19. stoletja, Giuseppe Tartini, Pierre (AndréNoël) Pagin, Joseph Terby ml., Leuven/Louvain, Leo Liepmannssohn, Berlin.
Abstract: The concertos by Tartini as well as several indexes to his concertos and sonatas, today preserved in the Staatsbibliothek zu Berlin-Preußischer Kulturbesitz, are the chosen focus of this article, especial attention being given to their provenance. All the concertos (38 manuscripts) and indexes (7) seem to belong to a collection whose provenance has not yet been clarified. The manuscripts can be traced back to Padua, the heart of Tartini's domain, and possibly also to Venice, with links to France as well as to nineteenth-century Belgium.

Keywords: eighteenth-century concerto, nineteenth-century collection, Giuseppe Tartini, Pierre (André-Noël) Pagin, Joseph Terby Jr., Leuven/Louvain, Leo Liepmannssohn, Berlin.

\section{Thematic Catalogues of Tartini's Concertos and Sonatas}

The Staatsbibliothek zu Berlin - Preußischer Kulturbesitz possesses seven handwritten indexes to Giuseppe Tartini's concertos and sonatas under the shelfmark Mus.ms.theor. Kat. 805. Already in 1972 Barry S. Brook drew attention to these indexes; ${ }^{1}$ since 2010 they have been accessible on the Internet. ${ }^{2}$

The first index, Kat. 805,1, consists of a single bifolio in oblong format: it is written on thick paper with an indecipherable watermark, of which only a few fragments are visible. The original title is Concerti del Sgr tartini. A pencilled note, "[Indice tematico

1 Brook, Thematic Catalogues in Music, 271.

2 See http://resolver.staatsbibliothek-berlin.de, Mus.ms.theor. Kat. 805. 
dei]", placed before the original title, was written later (probably by a librarian of the former Preußische Staatsbibliothek). The index provides incipits of 97 concertos (first movements only). One incipit has been entered twice (Nos. 61/84), so that in total 96 concertos are listed. Except for No. 73, inscribed "natale", all the concertos are listed in the Dounias catalogue; ${ }^{3}$ No. 68 has a different first movement. ${ }^{4}$ The incipits have been written in three different inks, used for Nos. 1-73, 74-94 and 95-97, respectively. The title and the form of abbreviation of the ordinal numbers ("n. $1^{0}$ ", "n. " $2^{\text {do", }}$ "n. ${ }^{\circ} 3^{\circ "}$, etc.) suggest that incipits 1-73 were written by an Italian hand..$^{5}$ Incipits 74-94 are entered in a similar style of handwriting and were apparently also the work of an Italian hand. The last three incipits, Nos. 95-97, were notated in haste (No. 95 is defective), and it appears that these were added by the second scribe. The index was possibly compiled towards the end of the eighteenth century. The duplicated entry for one concerto may possibly have been an error by the second scribe, but it could also signify that the index served as an inventory.

Two further indexes, Kat. 805,5 and 4, are notated on the same single folio in oblong format. Kat. 805,5 is captioned Inventaire General de touts men Biem | herités Dal ["Del" corrected to "Dal"] Sg. ${ }^{r}$ Giuseppe tartini. In the same hand appears a note written in perfect Italian in the upper left-hand corner: "Oltre - Le 12 Sonate Stampate Con la Pastorale."6 This index contains incipits for 48 sonatas (first fast movements). ${ }^{7}$ In the second index, Kat. 805,4, incipits for 63 concertos are entered (first movements only); these are notated on the verso of the sheet and headed Concerti. The Italian and French inscriptions show that they were written by a person, an Italian, whose command of written and spoken French was imperfect. The watermark (fragments of three crescents), the professional rastrography (10 staves ruled simultaneously) and the enclosure of the staves within vertical lines point to a scribe from the Veneto or the surrounding area. Since the works were apparently bequeathed by Tartini to the scribe, this person, who must have been in direct contact with the violinist, was very possibly a pupil of his.

The incipits for sonatas 1-37 and concertos 1-21 were entered by the inscriber of the titles; for concertos 5 and 14 he added "pastor.[ale]." The incipits for sonatas 38-40 and concertos 22-47 were written by a different hand. A third hand entered the last eight sonatas, numbered 9,2, 8, 5, 10, 4, 1 and 3. Their numbers correspond to those of the autograph sonatas by Tartini known as Sonate piccole. ${ }^{8}$ The incipits for concertos 48-63 are likewise written in this third hand. ${ }^{9}$ Given that there is more than one scribe, it is unclear whether literally all the listed sonatas and concertos were 'inherited' from Tartini. It is

3 See Dounias, Die Violinkonzerte, 247 ff.; No. 62 is listed in the Anhang; ibid., 297 (D Anh. VII).

4 The incipit of the first movement of No. 68 corresponds to that of It. 837 in the Berkeley catalogue, see Duckles, Elmer and Petrobelli, Thematic Catalog, 331. In the Dounias catalogue the concerto has a different first movement; see D 12 in: Dounias, Die Violinkonzerte, 251.

5 The title and these incipits were written in different shades of black ink. By two scribes?

6 Op. I, published by Le Cène in 1734 in Amsterdam; see Brainard, Le sonate per violino, xxxv-xxxvi.

7 Cf. Brainard, Le sonate per violino, $5 \mathrm{ff}$. On the numbering of the last eight sonatas, see below. The incipits of the "12 Sonate Stampate Con la Pastorale" were not transcribed in the index.

8 See Tartini, La raccolta di sonate autografe, $1 \mathrm{ff}$. Sonata 'III' is in error numbered 'IIII'.

9 A mistake made by the third scribe in the notation of the concerto incipits establishes that he copied from an index. After the incipit for No. 61 he entered under No. 62 in error the incipit for 
possible that this statement applies only to the works entered by the first writer. In addition, there are, as the word "Oltre" indicates, the "12 Sonate Stampate Con la Pastorale" mentioned at the head of the sonata index.

An annotation to the incipit of concerto 55 "envoyé [?...]yon | par Me[?; Mo?] Guillon [?; Guillou?; Goillan?]" suggests that the folio bearing the two indexes travelled to a Francophone area, probably France itself.

The same concertos are listed under Nos. 1-63 in Kat. 805,1 and 4. Differences in the notation of the incipits (longer incipits, rhythmic deviations, differences in the ornaments and in the placement of slurs and ties) show that Kat. 805,4 was not copied from Kat. 805,1. ${ }^{10}$ Obviously, the incipits in the two indexes were drawn from different sources. Kat. 805,5 and 4 were most likely written at a time close to that of Kat. 805,1, possibly towards the end of the eighteenth century.

Kat. 805,6, headed Motivi d Egli Concerti | del S:gr giuseppe tartini, consists of a single folio in oblong format. It presents the incipits of nine concertos (with all movements) in two columns and without numbering. In the left-hand column (inscribed "En $\mathrm{v}[\mathrm{e}] \mathrm{r}[\mathrm{so}]$ ") are two concertos in C major (Kat. 805,1/4: Nos. 20, 41); in the right-hand column (inscribed "En R[?]e[cto]") are two concertos in D minor (Kat. 805,3: No. 236, see below; Kat. 805,1/4: No. 4) and five in D major (Kat. 805,1/4: Nos. 30, 7, 48, 50, 42). Several words and abbreviations, such as "Double", "andanté", "1 1 er alleg." and " $2^{\mathrm{e}}$ alleg.", hint at a scribe from the Francophone area, probably from France. Kat. 805,6 seems to be the oldest of the indexes. The presence of the watermark "ANNONAY | 1742" proves that it was not written any earlier than $1742 ;{ }^{11}$ it was perhaps compiled between c. 1750 and c. 1780 .

Two indexes are the work of a single scribe: Kat. 805,7 and 2. Kat. 805,7, a bifolio in upright format (watermark: "B [heart] GOURBEYRE FIN | AUVERGNE 1742"), lists sonata prints by Tartini and is dated at the end: "Parie, le 28 mai 1854."12 The spelling 'Parie' for 'Paris' points to a writer from Belgium (Flemish Brabant). ${ }^{13}$ Kat. 805,2, a single folio in upright format (machine paper with no watermark), is a copy of Kat. 805,1, ${ }^{14}$ and was presumably written close to the time of Kat. 805,7 (c. 1850-55). The title Motivi d'Egli Concerti | del Signor Giuseppe Tartini leads one to assume that the writer was in the possession of Kat. 805,6 which has the same title.

The sonata index Kat. 805,5 contains, besides the original numbering, a different numbering for certain incipits (written in ink), entered by the writer of Kat. 805,2/7. Moreover, the pencilled notes for certain incipits are likewise in the hand of this scribe.

No. 63. He subsequently corrected the number 62 to 63 and then squeezed the incipit for No. 62 into the small space before No. 63 (to the left of the vertical line).

${ }^{10}$ Incipits $48-63$ in Kat. 805,4, written by a third hand, exhibit only some very small deviations.

${ }^{11}$ Regarding this date as it concerns French watermarks, see The Concertos.

${ }^{12}$ It appears that the scribe used old French paper. The index lists incipits for the first movements of Opp. 1-9; at the end of Op. 7 an incipit for the sonata "Le Trille" is given (B g5). It would appear that the entries were not all made at the same time. The incipits for Opp. 1-8 are written in an identical ink and exhibit a uniform style of handwriting, while the incipits for Op. 9 are written in a lighter ink and a more flowing style.

${ }^{13}$ For further information on this hand, see Provenance of the Collection.

14 The copy exhibits a few minor differences. 
The final index, Kat. 805,3, consists of a single folio in upright format (machine paper, no watermark), and is headed Concertos pour Violon avec acc. de quatuors par Tartini. This lists 25 concertos (first movements only) also inventoried, with identical numbering, in Kat. 805,1. There is in addition a final concerto numbered 236 that is absent from Kat. 805,1. This index, written in French and obviously an inventory (see The Concertos), was mostly compiled by two scribes. Numbers, incipits and descriptions of key are entered in an unsteady, trembling hand, from which one infers that they were entered by an elderly or perhaps infirm person. In contrast, title and tempo marks (for all movements) are entered in clear and legible handwriting. Apparently, the second scribe assisted the one responsible for the incipits in the compilation of the inventory. The last four incipits, numbered 95, 96, 97 and 236, were entered by a different hand that, on the basis of the musical handwriting, seems not to have belonged to a professional copyist or a musician. Kat. 805,3 has the appearance of being the most recent of the indexes. The concerto number ' 236 ' is a sure indication that the last four incipits were entered after 1879 (but before 1921; see Provenance of the Collection).

Apparently, the concertos listed by the first and second scribes of Kat. 805,3 were planned to be entered on the void pages of Kat. 805,1, as the notation of the numerals '4' (with its tempo marks Alle assai | Grave |Alle ${ }^{\circ}$ ) and '7' suggests. Kat. 805,3 begins with the concertos 4 and 7 . It appears that these entries were made by the second scribe of Kat. 805,3 .

It is remarkable that all the indexes of concertos and sonatas discussed above are connected in one way or another. Certain pencilled notes in German in Kat. 805,1/2/3/7 referring to the catalogues of Tebaldini $(1895)^{15}$ and Bachmann (1913) ${ }^{16}$ as well as to the published works of Tartini may have been made during the 1920s, when the Preußische Staatsbibliothek already owned the indexes (see Provenance of the Collection). There is nowhere any reference to the catalogue of Minos Dounias published in 1935. ${ }^{17}$

\section{The Concertos}

All 26 concertos listed in Kat. 805,3 - Concertos pour Violon avec acc. de quatuors par Tartini - are today held by the Staatsbibliothek zu Berlin - Preußischer Kulturbesitz. Four works have been transmitted in duplicate, and one in triplicate, which means that the total number of manuscripts rises to 32: Nos. 4, 7, 8, 10, 19, 20, 25, 26, 29, 30, 32, 41, 42, 45, 48, 50, 69 (3 mss.), 71 (2 mss.), 75, 78, 79, 87, 95 (2 mss.), 96 (2 mss.), 97 (2 mss.), 236. In addition, there are six manuscripts not listed in Kat. 805,3. These transmit concertos listed in Kat. 805,1 (and partly also in Kat. 805,4) under the numbers 2, 34, 39, 72, 74 and 76. The parts for concerto 2 have become split up by mistake: they are held by the Staatsbibliothek zu Berlin under two different shelfmarks. Almost all the manuscripts display, besides a handwritten number corresponding to that in Kat. 805,1(/4/3), a printed

15 Tebaldini, L’Archivio Musicale, 141-144.

${ }^{16}$ Bachmann, Les grands violonistes, 354-363.

${ }^{17}$ Dounias, Die Violinkonzerte, $247 \mathrm{ff}$. 
number. Small labels bearing these printed numbers have been pasted on to the title pages. The concerto with the printed number 236 is listed in Kat. 805,3 under the same number. ${ }^{18}$

On the basis of the watermarks, the copyists and various annotations, the total of 38 manuscripts can be divided into several categories:

1a) Manuscripts originating from the Veneto (Padua):

No. 4 (D 44), No. 20 (D 2), ${ }^{1}$ No. 69 (D 119), ${ }^{1}$ No. 71 (D 106), ${ }^{1}$ No. 95 (D 36), ${ }^{1}$ No. 96

(D 37), ${ }^{1}$ No. 97 (D 35).

1b) French parts occurring in manuscripts from the Veneto (Padua):

No. 2 (D 98): vl princ/fragment, "Basse"; No. 7 (D 32): vl I rip/II rip, cor I/II; No. 25 (D

49): “Basso", cor I/II; No. 32 (D 120): "Basso" (pp. 19-20).

1c) Other hands (not Italian) occurring in manuscripts from the Veneto (Padua):

No. 30 (D 20).

2) French manuscripts:

No. 8 (D 78), No. 10 (D 21), No. 19 (D 118), No. 26 (D 47), No. 29 (D 19), No. 34 (D

51), [No. 39] (D 8), No. 41 (D 7), No. 42 (D 28), No. 45 (D 90), No. 48 (D 26), No. 50

(D 24), ${ }^{2}$ No. 69 (D 119), No. 75 (D 53), No. 78 (D 11), No. 79 (D 31), No. 87 (D 122).

3) Manuscripts apparently from the Flanders region:

No. 236 (D 43).

4) Belgian manuscripts:

${ }^{3}$ No. 69 (D 119), ${ }^{2}$ No. 71 (D 106), No. 72 (D 66), No. 74 (D 110), No. 76 (D 84), ${ }^{2}$ No. 95

(D 36), ${ }^{2}$ No. 96 (D 37), ${ }^{2}$ No. 97 (D 35).

Apart from those in the fourth category, which were copied around the middle of the nineteenth century, all the manuscripts are copies made in the eighteenth century. A group of twelve manuscripts comes from the Veneto, possibly all from Padua (see groups 1a, $1 \mathrm{~b}$ and 1c above). The watermarks are characteristic of the Veneto; three crescents and a crossbow predominate. Three copyists already known to scholars as 'Berkeley A', 'Berkeley A1' and 'Berkeley D'19 belong to the Tartini circle and were active in Padua. 'Berkeley D' is Bernardino de Zotti, a violinist in the Cappella musicale of the Basilica of St. Anthony in Padua from 1721 up to his death in 1777. ${ }^{20}$ Eight manuscripts were copied by these three scribes: No. 2, No. 7, No. 25 (parts copied by 'Berkeley A1'); ${ }^{1}$ No. $69,{ }^{21}$ ${ }^{1}$ No. 95, ${ }^{1}$ No. 96, ${ }^{1}$ No. 97 (scores by 'Berkeley A'); ${ }^{1}$ No. 71 (parts by 'Berkeley D'). An autograph part by Tartini is attached to the score of ${ }^{1}$ No. 96 ; this transmits an embellished version of the Violino principale part for the slow movement.

Four out of the twelve manuscripts contain individual parts copied by old French hands (see category $1 \mathrm{~b}$ above). The horn parts for Nos. 7 and 25 are in the same hand, and the writer of the "Basse" part in No. 2 has also copied the vl I rip and vl II rip for No. 7 (regarding the French hands, see below). This shows that the manuscripts arrived in France from Italy during the course of the eighteenth century.

In No. 30 (see category 1c above), dated 1742 on its title page, corrections and comments by several old hands are made. Some corrections are seemingly in the hand of a

\footnotetext{
${ }^{18}$ Appendix 1 gives an overview of the numbers and shelfmarks of the concertos.

${ }^{19}$ Duckles, Elmer and Petrobelli, Thematic Catalog, 5.

${ }^{20}$ Ibid.

${ }^{21}$ See RISM Online Catalogue, D-B, Mus.ms. 21635/133, 'Read online', 25 ff.
} 
(French?) musician, ${ }^{22}$ and remarks such as "2 fois" and "f" or " $\mathrm{B}$ " over or under a few notes, point to the Flanders region.

The largest group comprises 17 manuscripts that all seem to be of French provenance (see category 2 above). Among the watermarks, the names and initials of some famous French paper manufacturers can be found, including those of P. Cusson, B. Gourbeyre, A. and R. Montgolfier, C. Pignion, J. Sauvade, A. and J. Vimal, and I V (Jean Villedary). ${ }^{23}$ On a largish number of manuscripts the year 1742 appears in the paper. "ANNONAY | 1742" or variants of this watermark appear in Nos. 10, 45, (50?), 75, 78 and 79. No. 48 features a grape with the year 1742, while Nos. 8, 19, 26, 42, 45, 50 and 87 have "AUVERGNE 1742."'24

One particular French copyist whom we will name 'Hand 1' copied six works either completely or partly: Nos. 8, 10, 19, 75, 78 and 79. A second "Basso" for the Italian manuscript No. 32 is probably also copied in this hand. ${ }^{25} \mathrm{~A}$ different French copyist, designated 'Hand 3', collaborated with 'Hand 1' in Nos. 75, 78 and 79. ${ }^{26}$

Special reference should be made to a French copyist termed by us 'Hand 2'. This person copied the orchestral parts for concerto 50, both strings and horns, as well as the horn parts for the concertos 7, 25, 10 and 42 (see categories $1 \mathrm{~b}$ and 2 above). ${ }^{27}$ In addition, this copyist added some names for parts in the Italian parts for concertos 7 and 25, as well as certain 'Solo'/'Tutti' directions in No. 25, and he made a few corrections to the French manuscript of concerto 42.

Two other concertos, Nos. 26 and 42, originate from a single copyist, No. 26 appearing to show a later stage of his musical handwriting.

No. 48 and ${ }^{2}$ No. 69 have French parts that were inexactly copied from scores. ${ }^{28}{ }^{2}$ No.

22 The script of this hand, especially the shape of the rests, is uncharacteristic of Italian manuscripts.

${ }^{23}$ Similar watermarks are illustrated in Gaudriault, Filigranes: Pl. 128 (ANF 12, 651, III. 4)/P [lily] CUSSON; Pl. 131 (ANF 12, 1478, A. IV)/B [heart] GOURBEYRE; Pl. 135/A [cross] MONGOLFIER, R [heart] MONGOLFIER; Pl. 137 (ANF 12, 1478, A. VIII)/C [heart] PIGNION; Pl. 141 (ANF 12, 1478, A. VI. 5)/A [heart] VIMAL; Pl. 141 (ANF 12, 650, XII)/J [heart] VIMAL; and in Churchill, Watermarks, CCCLXXXI (no. 516)/I [heart on two crossed swords] SAUVADE, CCCXXVII (no. 437)/I V [Jean Villedary] || bend and lily, below indistinct initials (possibly from a Dutch paper maker, I H?).

${ }^{24}$ The year signifies that the paper, on account of its format, conforms to an Arrêt of 18 September 1741. Paper bearing this date was manufactured over many years right up to the $1780 \mathrm{~s}$. So the presence of this year merely indicates that the manuscripts concerned were not copied before 1742. See Gaudriault, Filigranes, 27, and Massip, Les filigranes, 89.

${ }^{25}$ The manuscripts of this copyist evidence a change in handwriting. Concertos 8, 10 and 19 form a single group; Nos. 75, 78 and 79 another group. The French bass part for No. 32 matches the script of the second group. It is not clear which of the two groups represents the earlier writing stage of this copyist.

${ }^{26}$ The parts of this copyist exhibit some graphological variation: for instance, he employs different forms of crotchet rest. Possibly, this hand was involved also in the copies for concertos 19 and 87.

${ }^{27}$ The horn parts were probably added to the five concertos in France. Certain errors show that 'Hand 2' was not the composer of the horn parts.

${ }^{28}$ The copies go back directly or indirectly to scores in which the five parts were written in fourstave systems. No. 48 has been copied out in the manner of a sinfonia a quattro; in the solo sections $v l$ princ $=v l I ; v l I=v l I I ; v l I I=v l a$. In the vla part the copyist usually employs the bass clef for the solo sections while expecting the notes to be read in the treble rather than the bass or alto clef (in other places, however, an actual treble clef or a treble clef superimposed on a bass 
69 contains a loose folio on which a "Capricio" for the third movement has been notated. A pencilled annotation in the top left-hand corner, written in the hand of a librarian at the Preußische Staatsbibliothek and probably dating back to the 1920 s, claims this addition to be an autograph of Pagin. ${ }^{29}$

The provenance of concerto 236 (see category 3 above), listed in Kat. 805,3 in final position, is uncertain. Certain corrections in it lead to a supposition that the copy was produced in the Flanders area (possibly in Flemish Brabant). ${ }^{30}$

Eight manuscripts originate from Belgium (see category 4 above). For concerto 71, the writer of the indexes Kat. 805,2/7 prepared a score on the basis of the parts copied by 'Berkeley D' ('No. 71). This score, undated, was perhaps prepared in the $1840 \mathrm{~s}$ or $1850 \mathrm{~s}$. A second hand, similar to that of Kat. 805,2/7, copied parts for concerto 69 on the basis of the score made by 'Berkeley A' ('No. 69) ${ }^{31}$ and dated them 'Lovani | 1849."

Obviously, the scores of 'Berkeley A', Nos. 95, 96 and 97, were of special interest to the writer of Kat. $805,2 / 7$, since he made copies of the parts in close succession, as his datings prove: "(Louvain, 27 Août 1850.)"/No. 95, "Louvain, ce 30 Août 1850.”/No. 96, "Louvain, 31 Aout 1850"/No. 97. Two further concertos, Nos. 74 and 76, were also copied by the writer of Kat. 805,2/7, and No. 72, dated "Louvain. | 1850.", is in the hand resembling that of this scribe (see No. 69 above). The three exemplars are not preserved.

Except for No. 71, which is written on hand-made French paper, ${ }^{32}$ machine paper was used for all the nineteenth-century copies.

\section{Provenance of the Collection}

The manuscripts of concertos by Tartini held today by the Staatsbibliothek zu Berlin Preußischer Kulturbesitz together with the seven handwritten indexes of concertos and sonatas were accessioned on 17 June 1921 by the former Preußische Staatsbibliothek. ${ }^{33}$

clef is employed); see RISM Online Catalogue, D-B, Mus.ms. 21630, 'Read online'). In ${ }^{2}$ No. 69, $v l I$ and $v l I I$ have been exchanged in the solo sections: $v l I=v l I I, v l I I=v l I$; see RISM Online Catalogue, D-B, Mus.ms. 21635/133, 'Read online', 1 ff. Numerous small differences, mainly concerning slurring, show that the parts for ${ }^{2}$ No. 69 were not copied directly from the score of 'Berkeley A' ('No. 69).

${ }^{29}$ See RISM Online Catalogue, D-B, Mus.ms. 21635/133, 'Read online', 9. The pencilled annotation may have been made before 1935, since Dounias already mentions the Capriccio as being an autograph of Pagin; see Dounias, Die Violinkonzerte, 292 (D 119). For further information on Pagin's autographs, see Provenance of the Collection, passim.

${ }^{30}$ Remarks on corrected notes: "d", "re"; "ut", cropped. Watermark: L V G || Crowned double circle with an illegible circumscription, on the inside, fragments of a crowned lion on a pedestal with the inscription 'VRYHEYT'. For similar examples, see Voorn, De papiermolens, 173 (Nos. 104, 106).

${ }^{31}$ Today the score of 'Berkeley A' is in part no longer legible on account of ink corrosion; the Violino principale is for the most part completely obliterated.

${ }^{32}$ Watermark: grape with indistinct letters in a cartouche.

${ }^{33}$ See the accession journal of the Music Department: Musikabteilung, Accession. 1917-1925, 1921, 259-262. For concerto 69, existing in three copies, two manuscripts were recorded in the accession journal under M.1921.178 ( ${ }^{1}$ No. $69,{ }^{2}$ No. 69; Mus.ms. 21635/133). The third manuscript ( ${ }^{3}$ No. 
According to the accession journal of the Music Department, the concertos and indexes were acquired from the Berlin antiquarian firm of Leo Liepmannssohn, but obviously not at a public auction: the accession journal records " $T$ " (= Tausch), which means 'exchange'. It is not known to the Music Department from whom Otto Haas, at that time proprietor of Leo Liepmannssohn Antiquariat, acquired the manuscripts. ${ }^{34}$

There are no marks of ownership or names of copyists in the manuscripts. ${ }^{35}$ The two indexes Kat. 805,2/7, the concertos copied in Leuven (Louvain) in 1849 and 1850 and the two numberings of the manuscripts provide important information contributing to the clarification of the collection's provenance.

The collection, in the form in which it has come down to us today in the Staatsbibliothek zu Berlin - Preußischer Kulturbesitz, was assembled in the nineteenth century by the scribe responsible for the indexes Kat. 805,2/7. Six concertos in his hand have been transmitted. He copied three concertos in a row at the end of August 1850 in Leuven; in May 1854 he was in Paris, as the dating of Kat. 805,7 indicates. The handwritten numbering encountered on almost all of the concerto manuscripts originates for the most part from this writer, obviously following Kat. 805,1. ${ }^{36}$ The second numbering was carried out by means of small labels containing printed numbers that were pasted on to the manuscripts, as mentioned above. ${ }^{37}$

The annotations that the scribe of Kat. 805,2/7 made to the collection, and above all the two sets of numbering, reveal his identity. He is the violinist, conductor and composer Joseph Terby Jr. (Leuven, 1808-1879). The author of this article received the decisive information from Gilbert Huybens, who, on the basis of the 1879 sale catalogue of Terby's collection, was in a position to identify him clearly as the owner. ${ }^{38}$ Terby studied violin in

69; Mus.ms. 21635/134) was probably overlooked, or else it was received later (on the manuscript there is no accession number for it). Under M.1921.127 the accession journal indicates four thematic indexes. Kat. $805,2 / 3$, for which the accession number is not entered, were presumably seen as forming part of Kat. 805,1, and the indexes Kat. 805,5/4, written on a single folio, were obviously recorded as a single index. Dounias apparently did not know of several manuscripts in the Berlin collection, since he fails to list them in his index: No. 8/D 78, No. 48/D 26, ${ }^{3}$ No. 69/D 119 (Mus. ms. 21635/134) and No. 78/D 11; see Dounias, Die Violinkonzerte, 277, 257, $292,251$.

${ }^{34}$ I would like to thank Clemens Brenneis from the Music Department for the information in this paragraph, as well as for his great helpfulness and some clarificatory discussions with the author during her visits to the Staatsbibliothek zu Berlin. I would also like to express here my gratitude to the Music Department for generously facilitating my study of the original manuscripts.

${ }^{35}$ There is one exception; see No. 26 below.

${ }^{36}$ The spelling of the numbers corresponds, to a large extent, to the spelling in Kat. 805,2/7. The reading of the numeral 5 , sometimes mistakable for a 9 , causes some difficulties.

${ }^{37}$ For examples of the handwritten and printed numberings of the manuscripts, see the title page of No. 48 in: RISM Online Catalogue, D-B, Mus.ms. 21630, 'Read online'.

${ }^{38}$ I would like to express my gratitude to Gilbert Huybens, Stedelijk Conservatorium Leuven, for information on Joseph Terby's collection, as well as for mailing me copies of pages from the sale catalogue relevant to Terby's Tartini concertos. My thanks go also to Michael Talbot, University of Liverpool, and Els Scheers, Universiteitsarchief en Kunstpatrimonium Leuven, who kindly assisted me during my search for the 'collector from Louvain'. Further, I wish to thank David Peter Coppen from the Sibley Music Library, Eastman School of Music, University of Rochester, for his rapid sending of a digitized copy of the sale catalogue of 1879 . 
Paris, and was violin soloist and assistant conductor at the Théâtre-Italien. From 1860-1867 he succeeded his father as maître de chapelle at the Sint-Pieterskerk in Leuven. ${ }^{39}$

Two concertos also copied in Leuven in 1849 and 1850, but by a different hand ( ${ }^{3}$ No. 69, No. 72), probably originate from François Terby (1813-1884), Joseph's younger brother. He was a violinist, composer and teacher at the 'Section de Musique de l'Académie des Beaux-Arts' in Leuven. ${ }^{40}$

Joseph Terby, a passionate collector, assembled a remarkable collection of instruments, manuscripts and prints which, as a printed catalogue shows, was offered for sale after his death. The title page of the sale catalogue reads:

\section{CATALOGUE | DE LA BELLE COLLECTION DE | VIOLONS ITALIENS, | ARCHETS DE TOURTE, | MUSIQUE DE CHAMBRE ET MANUSCRITS PRÉCIEUX | des grands maîtres anciens et modernes, | DÉLAISSÉE PAR FEU | M MOSEPH TERBY, | ancien $1^{\mathrm{r}}$ violon-solo $\mid$ du Théâtre impérial Italien de Paris et maître de chapelle $\mid$ de l'église de St-Pierre à Louvain; | dont la vente publique aura lieu en cette ville, | le Jeudi 17 Juillet 1879, | A 2 1/2 HEURES PRÉCISES, | Rue Craenendonck, $N^{0} 1 .^{41}$}

The manuscripts of the Tartini concertos belong, without doubt, to the most valuable items in the Terby collection. In the sale catalogue they are listed under the title Manuscrits des Concertos, pour Violon principal, | avec accompagnement de 3 ou 4 parties, par G. Tartini. ${ }^{42}$ They display two numbers: the first gives the item number in the sale catalogue ("Nos du | Catalogue"), while the second refers to the (handwritten) number of the concerto ("Nos d'ordre | des Concertos"). A comparison between the numberings in the sale catalogue and those appearing on the manuscripts shows that the Tartini concerto manuscripts owned by Terby passed almost in their entirety to the Staatsbibliothek zu Berlin - Preußischer Kulturbesitz:

Of the 40 manuscripts listed in the sale catalogue (201-240), five are no longer available: $204 / 8$ bis, $207 / 19$ bis, $212 / 30$ or $213 / 30$ bis, $218 / 45,227 / 75$. Since concerto 30 has no printed number, it is impossible to establish whether manuscript $212 / 30$ or 213/30bis is missing. ${ }^{43}$ The collection contains in addition three manuscripts not listed in the sale catalogue: No. 2, [No. 39], No. 69. On No. 2 the handwritten number was entered by Terby; for No. 39 the original cover is missing, and with it the number. ${ }^{44}$ Regarding No. 69 , it is unclear which manuscript is intended by No. 222 in the sale catalogue, since two of the manuscripts transmitting it do not have a printed number $\left({ }^{1}\right.$ No. $69,{ }^{3}$ No. 69$) .{ }^{45}$

${ }^{39}$ For more information on Terby's biography, see Huybens and Robberechts, Frascati, 92; Pougin, "Terby, Joseph," 569; Roquet, "Terby, Toussaint Joseph," 673.

${ }^{40}$ Pougin, "Terby, Joseph," 569; Roquet, "Terby, François-Pierre," 673. See also Huybens, Het Muziekconservatorium, 97, 100 (Afb. 24 with F. Terby's signature), 101, 134.

${ }^{41}$ See Appendix 2, Figure 1.

${ }^{42}$ See Appendix 2, Figure 2/pp. 13-14.

${ }^{43}$ Some of the tiny labels have probably become detached from the title pages in the course of time, since several manuscripts possess no printed number.

${ }^{44}$ Thus in the case of this manuscript there is no cast-iron evidence that it belonged to Terby's collection. The pencilled note "[Concerto N. . 39]" on the $v l$ I part was added by the Preußische Staatsbibliothek.

${ }^{45}$ However, since ${ }^{3}$ No. 69 is a copy of ${ }^{1}$ No. 69 , it may be assumed that both manuscripts belonged to the collection. 


\begin{tabular}{|c|c|c|c|}
\hline \multicolumn{2}{|c|}{ Sale catalogue 1879} & \multicolumn{2}{|c|}{ Manuscripts in D-B } \\
\hline Catalogue numbers & Concerto numbers & Printed numbers & Handwritten numbers \\
\hline & - & & 2 \\
\hline 201 & 4 & 201 & 4 \\
\hline 202 & 7 & 202 & 7 \\
\hline 203 & 8 & 203 & 8 \\
\hline 204 & 8bis & & \\
\hline 205 & 10 & $203[\mathrm{sic}]^{*}$ & 10 \\
\hline 206 & 19 & 206 & 19 \\
\hline 207 & 19bis & & \\
\hline 208 & 20 & 208 & 20 \\
\hline 209 & 25 & 209 & 25 \\
\hline 210 & 26 & 210 & 26 \\
\hline 211 & 29 & 211 & 29 \\
\hline 212 & 30 & - & 30 \\
\hline 213 & 30bis & & \\
\hline 214 & 32 & 214 & 32 \\
\hline 215 & 34 & - & 34 \\
\hline & - & & [39] \\
\hline 216 & 41 & 216 & 41 \\
\hline 217 & 42 & 217 & 42 \\
\hline 218 & 45 & & \\
\hline 219 & 45bis & 219 & 45 \\
\hline 220 & 48 & 220 & 48 \\
\hline 221 & 50 & 221 & 50 \\
\hline 222 & 69 & - & 69 \\
\hline 223 & 69bis & 223 & 69 \\
\hline & - & & 69 \\
\hline 224 & 71 & 224 & 71 \\
\hline 225 & 72 & - & 72 \\
\hline 226 & 74 & 226 & 74 \\
\hline 227 & 75 & & \\
\hline 228 & $75 \mathrm{bis}$ & 228 & 75 \\
\hline 229 & 76 & 229 & 76 \\
\hline 230 & 78 & 230 & 78 \\
\hline 231 & 79 & 231 & 79 \\
\hline 232 & 87 & 232 & 87 \\
\hline 233 & 95 & 233 & 95 \\
\hline 234 & 96 & 234 & 96 \\
\hline 235 & 97 & 235 & 97 \\
\hline 236 & unnumbered concerto & 236 & - \\
\hline 237 & score of no. 71 & - & 71 \\
\hline 238 & 95 & 238 & 95 \\
\hline 239 & 96 & 239 & 96 \\
\hline 240 & 97 & 240 & 97 \\
\hline
\end{tabular}

* '203' is probably an error for ' 205 '. 
The sale catalogue of Terby's collection informs us in a subtitle (p. 13) that the major part of the listed Tartini concertos was unpublished: La plupart de ces Concertos sont inédits. ${ }^{46} \mathrm{~A}$ note to this subtitle (foot of p. 13) provides valuable information on the provenance of the concertos: "Tartini les légua à son élève favori Pagin et M. Terby eut la bonne fortune de les acquérir après le décès de l'un des descendants de ce dernier." ("Tartini bequeathed them to his favourite pupil Pagin and Mr. Terby had the good fortune to acquire them after the death of one of the latter's descendants.") Pagin, a French violinist and composer, received lessons in his early youth from the Maestro in Padua (around 1739/40). ${ }^{47}$ In all probability, the concertos that Tartini left to Pagin are manuscripts that this violinist brought to Paris in the 1740 s on his return from Padua.$^{48}$ This in turn implies that we should look for the 'Pagin' concertos primarily among the Italian/Paduan manuscripts, plus the manuscripts containing individual Italian/Paduan and French parts. However, Pagin certainly also owned manuscripts of French provenance (most likely copied from his Paduan manuscripts). As the playwright Pierre Laujon (1727-1811) writes, he was a member of the orchestra of the Count of Clermont. ${ }^{49}$ Therefore, it seems reasonable to infer that 'Hand 1' and 'Hand 3' were copyists working for the Count's orchestra. ${ }^{50}$ 'Hand 2' was presumably a musician, as his corrections to No. 42 suggest, but whether he belonged to the circle of musicians around the Count of Clermont remains an open question. ${ }^{51}$

There are some clues within the collection suggesting that the manuscripts in 'Hand 1' and 'Hand 2' especially, and also those of the Tartini copyist 'Berkeley A1', are connected with Pagin. Regarding Nos. 2, 8, 10 and 25 as well as concerto 42, which originates from a different copyist (with horn parts and corrections in 'Hand 2'), autograph Capricci by Pagin have come down to us; for concertos 2, 10 and 42, autograph cadenzas by Pagin are also preserved. ${ }^{52}$ In Nos. 7 and 50, in the Violino principale, short passages

${ }^{46}$ Pougin mistakenly refers (in 1880) to "manuscrits autographes de plusieurs concertos inédits de Tartini”; see Pougin, “Terby, Joseph," 569. Published in old prints: No. 8 (D 78), No. 20 (D 2); see Dounias, Die Violinkonzerte, 277, 247-248. [Published arrangements: No. 2 (D 98, not listed in the sale catalogue), No. 7 (D 32), No. 45 (D 50); No. 32 (D 120), No. 75 (D 53), No. 95 (D 36); see ibid., 284, 259-260, 266; 292-293, 267, 261.]

${ }^{47}$ Regarding this, see Wilcox, The Hissing of Jean-Pierre Pagin, 104.

${ }^{48}$ Pagin made his debut at the Concert Spirituel on 8th December 1747; see Fay and Barbieri, "Pagin, André-Noël," 897. He possibly returned to Paris already in 1745; see Wilcox, The Hissing of Jean-Pierre Pagin, 105.

49 "Un orchestre nombreux, composé en partie des différentes personnes qui lui étaient attachées, tels que MM. Pagin, Blavet, etc., variait, par des concerts, les plaisirs du prince et de ceux qu'ils attiraient à sa Cour: [...]"; see Laujon, Euvres choisies, xi. Cousin quotes this passage in a section dated "Aout 1747"; see Cousin, Le comte de Clermont, 2-4. In 1759 Pagin is mentioned as being first violinist in the Count's orchestra; see SL/(Wirsta), "Pagin, André-Noël," col. 1555.

${ }^{50}$ The copy of a concerto attributed to La Houssaye, appears to be in 'Hand 1'. The manuscript, originally anonymous, likewise belonged to Terby's collection; the inscription "Lahoussaie" on the title page is apparently in Terby's hand (for more information, see below). La Houssaye, a pupil of Pagin and Tartini, was in the employ of the Count of Clermont (before 1753); see Cooper, "La Houssaye, Pierre-Nicolas," 117.

${ }^{51}$ The string parts for No. 10 are in 'Hand 1', the horn parts in 'Hand 2'.

${ }^{52}$ See the Capricci for the last movements (indicated at the end variously by a written-out cadenza or the direction "Cadenza") on pages 4 (No. 2), 5/second Capriccio (No. 2), 22 (No. 8), 5/first 
written in a contemporary musician's hand are added, apparently by Pagin. ${ }^{53}$ Today it is no longer possible to establish whether the Capriccio to concerto 69, written on a loose folio, belonged originally to the French parts $\left({ }^{2} \mathrm{No} .69\right)$ or to the score by 'Berkeley A' ('No. 69), or whether it was stored together with the other Capricci by Pagin (see above). A further manuscript, No. 29, appears to be a copy made by Pagin. ${ }^{54}$

We may speculate that Pagin played some of these concertos at the end of the $1740 \mathrm{~s}$ at the Concert Spirituel in Paris. ${ }^{55}$ Concerto 25, for example, stands out in a particular way, not only on account of its employment of a larger ensemble with strings and horns, but even more on account of the extraordinary Capriccio of 110 measures (followed by a Cadenza) that Pagin composed for the third movement. ${ }^{56}$

Two further concertos, Nos. 34 and 45, seem likewise to be connected with Pagin. Additional parts for a violin concerto by G. B. Pergolesi originating from the Terby collection have been supplied by the two copyists of those concertos as well as by the principal copyist of concerto 42, which obviously belonged to Pagin's repertoire (see above).$^{57}$ An autograph Capriccio by Pagin, motivically related to the fourth movement of the Pergolesi concerto, suggests, moreover, that Pagin himself performed this work. ${ }^{58}$ It is therefore possible that the manuscript of the Pergolesi concerto was once in his possession and perhaps lay among the manuscripts of the Tartini concertos that Terby received from his family later.

With regard to several manuscripts, there are hints that they had other previous owners. The Name "M Duval" in the lower right-hand corner of the title page of concerto 26 possibly hints at a previous owner, ${ }^{59}$ and concerto 236 is apparently a copy from the

Capriccio (No. 10), 1 (No. 25), 14 (No. 42) and the Cadenze on pages 3 (No. 2/movements 1 and 2), 6 (No. 10/movement 1), 13 (No. 42/movement 1: the "Cadenza p. ${ }^{\text {ma" }}$ is to be performed before the second ritornello [bar 35]; the customary cadenza before the final ritornello begins on the third staff) in the RISM Online Catalogue, D-B, Mus.ms.autogr. Pagin, P. 1 M, 'Read online' (pencilled pagination added in 2013). The manuscript most probably belonged to the collection of Joseph Terby (see below).

${ }^{53}$ In No. 50, at the end of the $v l$ princ, a virtuosic passage of 30 bars is notated without any heading; this is probably a Capriccio, but is apparently not in the hand of Pagin. It is followed, however, by a short passage that could have been written by Pagin.

${ }^{54}$ There are some differences between the notation of the Violino principale and that of the other parts. Similarities to Pagin's autograph manuscripts, which likewise exhibit some variation in their notation, show that, notwithstanding this, all the parts may have been written by his hand. For more details regarding Pagin's autographs, see below.

${ }^{55}$ See Fay and Barbieri, "Pagin, André-Noël," 897.

${ }^{56}$ See note 53 (p. 1).

${ }^{57}$ Two duplicate parts of the $v$ l princ (one partly missing) were prepared by the copyists of No. 42 and No. 45, respectively. Two duplicates of the $v l I I$ (one partly missing) as well as four copies of the $b$ rip, probably all of them performance parts, originate from the copyist of No. 34. A second copy of the Pergolesi concerto (incomplete) in Terby's hand exists. For further information, see below.

${ }^{58}$ See the "Capricio" on page 18 in the RISM Online Catalogue, D-B, Mus.ms.autogr. Pagin, P. $1 \mathrm{M}$, 'Read online'.

${ }^{59}$ This "M" could stand for "Monsieur." Since the parts were copied by the principal hand of No. 42, a connection to Pagin is possible also for this concerto (its handwriting suggests a later date 
Flanders area. A few entries in concerto 30 offer clues to its possible ownership by a person from the Flanders area before it came into Terby's possession. Moreover, three scores copied by 'Berkeley A', Nos. 95, 96 and 97, do not seem to have been owned by Pagin (see below). Finally, reasonable doubts are in order concerning the defective manuscripts of No. 48 and ${ }^{2}$ No. 69.

So some of the Italian and French manuscripts can definitely be connected with Pagin, although it is impossible to say exactly how many manuscripts were owned by him because of missing entries. However, it can be stated without fear of contradiction that Pagin's concerto manuscripts make up an important part, or even the largest part, of Terby's collection of Tartini concertos.

It remains an open question how the indexes Kat. 805,6 and Kat. 805,1/4/5 found their way into Terby's collection and who was their earlier owner; they are not mentioned in the sale catalogue of 1879. All nine works listed in the French index, Kat. 805,6 (Nos. 4, 7, 20, 30; Nos. 41, 42, 48, 50; No. 236), are transmitted in the collection, but it is not possible to establish a direct connection to all those manuscripts, since some, such as Nos. 30 and 236, seemingly had Flemish owners.

The Italian indexes, Kat. 805,1 and Kat. 805,4/5, are rather puzzling. They seem to have all been compiled in the same place, possibly Padua or Venice, and they probably remained together during their onward transmission. Kat. 805,4 was not copied from Kat. 805,1 , but both indexes list the same concertos under the numbers $1-63 .{ }^{60}$ Clear parallels are also evident in the style of their titles: Concerti del Sgr tartini (Kat. 805,1), Concerti (Kat. 805,4) and [...] Sg. ${ }^{r}$ [...] tartini (Kat. 805,5). On the basis of the handwriting, all three titles could have been written by a single hand. Further parallels exist in the notation of the incipits - for example, in their terminal markings.

The title of Kat. 805,5, Inventaire General de touts men Biem | herités Dal Sg. ${ }^{r}$ Giuseppe tartini, suggests that the writer had inherited music from Tartini. This French title, in the hand of an Italian, suggests that the Inventaire was compiled for the benefit of a Frenchman, possibly towards the end of the eighteenth century during the period of French rule in the Veneto (c. 1797; 1805-1814?). Kat. 805,1 may similarly have the function of an inventory, but it remains unclear whether it was prepared at the behest of the same person, and whether it lists concertos that he owned. However, differences between the notation of the incipits in Kat. 805,1 and Kat. 805,4 seem to indicate that more than one manuscript of the concertos Nos. 1-63 was available.

The Italian indexes of the concertos (Kat. 805,1/4) cannot clearly be linked to the Italian manuscripts today held by the Staatsbibliothek zu Berlin - Preußischer Kulturbesitz.

for the copy of No. 26; see The Concertos). Perhaps "M[onsieur?] Duval" was not the original owner of the manuscript.

${ }^{60}$ In other Italian catalogues from the eighteenth century the following concertos are listed under the identical numbers: Nos. 1, 22 and 41 in 'Berkeley B' (US-BEm, It. 1018b), No. 74 in 'Berkeley A' (US-BEm, It. 1018a), Nos. 7 and 10 in a Modenese catalogue (I-Mol, Ms. G.A. 595bis). The annotation "pastor.[ale]" on Nos. 5 and 14 in Kat. 805,4 occurs also in a catalogue in Ancona (I-AN, Ms. Mus. T-45), the incipits have not, however, been numbered there. I am indebted for the opportunity to inspect copies of these still unpublished catalogues to Margherita Canale, Conservatorio di musica "Giuseppe Tartini", Trieste. 
Most of them probably arrived in France prior to the compilation of the indexes. Further, there is no old numbering on the Italian manuscripts that could be used to establish a clear connection to the Italian indexes. Three scores in the hand 'Berkeley A' are exceptional for displaying an old numbering in the top left-hand corner of their title pages: "95.", "96.", "97. ." The abbreviation "97." provides a hint that the Paduan manuscripts were numbered by a French hand and/or in the Francophone area. The connection between Kat. 805,1 and the three scores by 'Berkeley A' arising from their numbering suggests that they were owned by a single person in the Francophone area before finding their way into Terby's collection. ${ }^{61}$ However, the copy of concerto 69 probably made by François Terby provides a hint through its dating, "Lovani | 1849", that the Terby family already owned Kat. 805,1. In all the parts, the concerto's number and its title were written at the same time: N. ${ }^{\circ}$ 69. Concerto del Sig. ${ }^{r}$ Giuseppe Tartini.

Who acquired Terby's collection of Tartini concertos in 1879, and who owned it between 1879 and 1921, both remain unresolved questions. ${ }^{62}$ It may be presumed that scribe 1 of the inventory Kat. 805,3 took over the collection. Among the manuscripts there are no copies made by this scribe, but the manner in which the incipits are notated suggests that he was a musician, probably from Belgium or France. It remains unclear why scribes 1 and 2, and scribe 3 likewise, did not list in Kat. 805,3 all the concertos belonging to the collection, of which six are absent.

The lot acquired by the Preußische Staatsbibliothek from Leo Liepmannssohn Antiquariat and accessioned on June 17, 1921 contained further works by Tartini: two sonata collections, ${ }^{63}$ two sonatas in G major and a further one in A major entitled "Solo", ${ }^{64}$ as well as one Arpeggio. ${ }^{65}$ The sonata manuscripts are French, while the Arpeggio (first copy) seems to originate from the Veneto. In addition, the lot included two manuscripts, apparently autographs, by Pagin, one of which contained Capricci, Cadenze and sketches, and the other a Trio sonata in D major, ${ }^{66}$ plus two anonymous concertos. ${ }^{67}$ All these manuscripts, or at least a portion of them, were owned in the nineteenth century by Joseph Terby Jr. Entries made in his hand occur in the two sonata collections, ${ }^{68}$ and he made a

${ }^{61}$ Whether there is a link to the Tartini compositions in Paris brought from Italy to the Conservatoire (today, the Bibliothèque nationale de France, fonds du Conservatoire), presumably towards the end of the eighteenth century (before 1827), needs to be examined more closely; see Brainard, Die Violinsonaten, 88-92, and Pougin, Le Violon, 111-112.

${ }^{62}$ At present, the papers and correspondence of the pre-1935 era of Otto Haas are inaccessible. My informant is Julia Rosenthal, proprietor of Otto Haas London (formerly Leo Liepmannssohn Berlin).

${ }^{63}$ Mus.ms. 21636/1, Mus.ms. 21636/2 (last sonata, fragment, by Martin Berteau).

${ }^{64}$ Mus.ms. 21636/64; Mus.ms. 21636/60, Mus.ms. 21636/12. Folios belonging to the sonatas Mus. ms. 21636/60 and Mus.ms. 21636/12 have been jumbled up by mistake and incorrectly stitched.

${ }^{65}$ Mus.ms. 21637 (2 mss.).

${ }^{66}$ See RISM Online Catalogue, D-B, Mus.ms.autogr. Pagin, P. 1 M, 'Read online', and D-B, Mus. ms.autogr. Pagin, P. 2 M, 'Read online'.

${ }^{67}$ Mus.ms.anon. 1028, Mus.ms.anon. 912.

${ }^{68}$ In Mus.ms. 21636/1 the title, Sonates par Giuseppe Tartini, the "Capricio" of concerto 26 (notated on a small folio and pasted beneath the title) and the numbers written in the upper margin of the title page are all in Terby's hand, as is also the pagination added in pencil. In Mus.ms. 21636/2 remarks made by Terby, such as "2. e Sonate de l'Euvre 7" (f. 18v), are present. The sale catalogue 
copy of the Arpeggio. The attribution to Tartini, “attribuée à Tartini”, found on the title page of the sonata in G major shelfmarked Mus.ms. 21636/64 may have been written by Terby. In the Pagin autographs there are no annotations made by Terby, but one may assume that the latter obtained them together with Pagin's Tartini concertos. ${ }^{69}$

The manuscript containing Capricci and Cadenze is of particular interest for performance practice, since it is possible that they are all (or almost all) autographs by Pagin. ${ }^{70}$ The manuscript consists of loose folios made up of 10 single folios and one bifolio; the paper is French. ${ }^{71}$ The first Capriccio is inscribed CapriCio Del ConCerto in elami Di pietro Pagin. ${ }^{72}$ A short musical passage, untitled, is dated " 8 aoust 1780 ." To what extent the Capricci and Cadenze can be assigned to definite Tartini concertos and sonatas needs closer investigation. Some of them, as noted above, are associated with concertos in Terby's collection. Pagin established himself in Paris not only as a notable interpreter of Tartini's music but also as an interpreter of Vivaldi's concertos. ${ }^{73}$ His Capricci for the outer movements of the concerto in E major "La primavera" (RV 269) confirm that he appeared as a soloist in this famous work by Vivaldi. ${ }^{74}$

Four concertos in the Terby collection - by Pergolesi (1), La Houssaye (1) and Touchemoulin (2) - listed under lots 241, 242 and 243 in the sale catalogue of 1879, are held by the Library of Congress in Washington, D.C. ${ }^{75}$ The manuscripts were, as a list of orders made by the Library of Congress shows, purchased from Leo Liepmannssohn Antiquariat on 19 July $1921 .^{76}$ From this list one also learns that Liepmannssohn Antiquariat offered the manuscripts for sale to the library in a list from the firm dated 29 May 1921 (a second list is dated 31 May 1921). It follows that Liepmannssohn Antiquariat purchased

of 1879 lists mostly sonata prints by Tartini. With regard to the manuscripts listed under lot 165 , "Tartini, Sonates copiées", there are no detailed descriptions.

${ }^{69}$ A "Paquet de hasard", lot 245 in the sale catalogue, provides no more information on the manuscripts it contains (see Appendix 2, Figure 2/p. 14). Perhaps it contained some items by Tartini, such as the Arpeggio and the separately transmitted sonatas, plus the autographs by Pagin and the anonymous concertos.

${ }^{70}$ A short passage headed "Allegro" on the first staff of page 13 (see note 67, Mus.ms.autogr. Pagin, P. $1 \mathrm{M}$ ) seems to be written in a different hand.

${ }^{71}$ Italian watermarks cannot be detected in them. For the notation of two Capricci (pp. 1, 23), as well as that of the Capriccio for concerto 69 and the trio sonata by Pagin (see above), a similar, very thin French paper was employed (watermarks: griffin, J[?; heart, lily above] CUSSON, I[?; heart, lily above] CUSSON MOYEN). It appears that the autographs by Pagin originate from the period following his return from Padua, thus after c. 1745.

${ }^{72}$ The title confirms that Pagin's first name was Pierre. The appellation André-Noël often given in specialist literature can be traced back to an error in the Biographie universelle des musiciens by François-Joseph Fétis; see Wilcox, The Hissing of Jean-Pierre Pagin, 107-108.

${ }^{73}$ See Fay and Barbieri, "Pagin, André-Noël," 897.

${ }^{74}$ See RISM Online Catalogue, D-B, Mus.ms.autogr. Pagin, P. 1 M, 'Read online', 9, 17 (two versions of the Capriccio exist for the last movement).

${ }^{75}$ M1012.P45P Case; M1012.L2 Case; M1012.T71 Case, M1012.T715 Case. For information on the catalogue numbers, see Appendix 2, Figure 2/p. 14.

${ }^{76}$ I am grateful to Samuel Perryman from the Music Division for sending me a digital scan of the list of orders and other information. 
the items formerly in the Terby collection, today held in Berlin (D-B) and Washington, D.C. (US-Wc), from the same owner and before 29 May 1921.

It appears that Joseph Terby was a great admirer of Tartini's music. It may have been Terby's teacher André Robberechts, a pupil of Baillot and Viotti, who awakened his interest in the Maestro delle nazioni. ${ }^{77}$ Terby lived in Paris for 34 years (1825-c. 1859/60), as the 1879 sale catalogue of his collection points out. During his long sojourn in one of the most important music centres in Europe he had the opportunity to purchase a significant number of manuscripts, prints and instruments. The manuscripts of Terby's 32 Tartini concertos are almost completely preserved (38 are still extant, while five are missing), a fact that has to be viewed as a great stroke of luck for researchers. The concertos were preserved in the custody of musicians over a long period during the eighteenth and nineteenth centuries. Inquiries in Leuven may perhaps provide additional information on the circulation of the manuscripts in the nineteenth century and the second half of the eighteenth century.

\section{Appendix 1}

\section{The Tartini concertos in the Staatsbibliothek zu Berlin - Preußischer Kulturbesitz ${ }^{78}$}

Numbering
by Dounias $^{79}$

D 98 are in a French hand; $v l I / v l$ II were copied by 'Berkeley Al'. The remaining parts are in Mus.ms. 21635/113.

D 98

\author{
Handwritten \\ numbers $^{80}$
}

\section{Printed}

numbers $^{81}$

\section{Shelfmarks}

Mus.ms. 21635/110

Remarks: Vla and b rip have been written by 'Berkeley A1'. A second "Basse" is in a French hand; the same hand copied the $v l$ I rinf and $v l$ II rinf in No. 7. The remaining parts are in Mus.ms. 21635/110.
D 44
No. 4
201
Mus.ms. 21635/57

Remarks: Manuscript parts from the Veneto. The copy has been made by a single copyist; the incipit on the title page is in a different hand.
D 32
No. 7
202
Mus.ms. 21635/47

Remarks: Vl princ, vl I, vl II, vla, b are copied by 'Berkeley A1'. Vl I rinf, vl II rinf are by a French copyist; the same hand copied the "Basse" in No. 2 (Mus.ms. 21635/113). Cor da caccia I/II and the part names at the end of $v l I, v l I I$ are in 'Hand 2'. A short passage at the end of the $v l$ princ is apparently by Pagin.

D 78 No. $8 \quad 203 \quad$ Mus.ms. 21635/100

Remarks: Manuscript of French provenance. All the parts are in 'Hand 1'.

77 See Fétis, "Robberechts, André," 276.

${ }^{78}$ Additions by the author are given in square brackets. Different sources for the same concerto are distinguished by different introductory superscript numbers.

${ }^{79}$ See Dounias, Die Violinkonzerte, $247 \mathrm{ff}$.

${ }^{80}$ Unless stated otherwise, the handwritten numbers have been entered by Joseph Terby Jr.

${ }^{81}$ Small labels with printed numbers were pasted on to the manuscripts in 1879 , when the Terby collection was sold. 
D $21 \quad$ No. 10203 [sic] Mus.ms. 21635/44

Remarks: Manuscript of French provenance. String parts in 'Hand 1', cor da caccia I/II in 'Hand 2'.

D 118 No. $19206 \quad$ Mus.ms. 21635/141

Remarks: Manuscript parts of French provenance. Almost all the parts are in 'Hand 1'; the third movt of the vl princ is in a second hand ('Hand 3'?; cf. No. 87).

$\begin{array}{llll}\text { D } 2 & \text { No. } 20 & 208 & \text { Mus.ms. 21635/13 }\end{array}$

Remarks: Manuscript parts from the Veneto. The copy has been made by several hands. The Cadenza for movt 3 at the end of the $v l$ princ is in the hand of its copyist.

D 49 No. $25 \quad 209 \quad$ Mus.ms. 21635/77

Remarks: Vl princ, vl I, vl II, vla, vlc are copied by 'Berkeley Al'. The remaining parts are in three different hands. The "Contra Basso" could be French or Italian (no watermark); the "Basso" is French (probably a copy from the "Contra Basso"). Cor da caccia I/II ("ad Lib.") are in 'Hand 2'. The part names at the end of $v l$ I, vl II and $v l c$, as well as a few 'Solo'/"Tutti' directions in the vlc, "Contra Basso" and "Basso" (movt 3), have also been entered by 'Hand 2'. "Tartini", on the title page of the "Basso", has been added by Joseph Terby.
D 47
No. 26
210
Mus.ms. 21635/74

Remarks: French manuscript parts, written in a single hand; the same hand copied the string parts in No. 42. The title and incipit on the title page are by a different hand or hands; see also No. 45. In the lower right-hand corner of the title page the name "M Duval" appears.
D 19
No. 29
211
Mus.ms. 21635/35

Remarks: Manuscript parts of French provenance. The copy was probably made by Pierre Pagin. Title apparently in the hand of the copyist; the incipit on the title page is in a different hand. "Tartini", added in pencil above the incipit, is in a later hand. The letter " $\mathrm{B}$ " is written in an old hand at the top of the title page. Some corrections show that the parts have been copied from a score. The third movt of $v l$ II was not copied in its entirety.
D 20
No. 30
Mus.ms. 21635/41

Remarks: Manuscript from the Veneto dated 1742 on the title page. Almost all parts are in one hand; the Violetta is in a second hand. The Cadenza for movt 3 at the end of the vl princ is in the hand of the copyist; the following Capriccio (untitled), notated on the next page, is possibly in the same hand. Corrections, additions and comments made by several old hands can be found. Annotations and musical symbols (in different hands): "cadenza" and fermata to indicate a cadenza for the soloist (movements 1 and 2); " $\mathrm{f}$ " (1x), "B" (2x) on individual notes, " 2 fois." In the $v l$ princ, at the end of movt 2 , a short cadenza is added in a musician's hand.

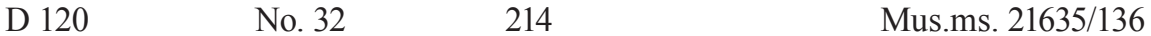

Remarks: Manuscript parts from the Veneto; one copyist. A second "Basso" (pp. 19-20) is in a French hand (probably 'Hand 1'). On an old(er) fold reinforcement in the top left-hand corner of the title page appears a number: "5." In the slow movt of the $v l$ princ the notes of $v l I$ and $v l I I$ were partly added in a 'pointed' manner; a sketch of a few notes is possibly in the same hand. At the end of the $v l$ princ Terby has noted: "adagio et finale très beau."
D 51
No. 34
Mus.ms. 21635/71

Remarks: The sole extant part is the $v l$ princ; the copy is of French provenance.

D 8

[No. 39]

Mus.ms. 21635/10

Remarks: Manuscript of French provenance; one copyist. The vla is missing, vl princ is incomplete (title page, beginning of movt 1 and the ending of movt 3 are missing).

\section{7 \\ No. 41 \\ 216 \\ Mus.ms. 21635/7}

Remarks: Manuscript parts of French provenance, written in a single hand. The original title page plus, on its verso, the notation of the first and second movements of the bass part, is partly missing. On the last page of 
the bass part Terby has written: " ${ }^{\mathrm{er}}-$ en la mineur $-\mid 19--$ Adagio et Allegro. $|20-| 25-|30-| 41-|45-|$ $69-|72-| 74-|75-| 76-|95-| 96-\mid 97-. "$ Almost all these numbers refer to concertos in the collection.
D 28
No. 42
217
Mus.ms. 21635/40

Remarks: Manuscript of French provenance. All the string parts are in a single hand, apparently an earlier stage of the copyist's hand shown in No. 26. In the vl I rinf and $v l$ II rinf the last tutti of the second movt has been added by a different hand in a lighter ink. Some 'tutti' and 'Solo'/'Soli' directions, dynamic marks, slurs, corrections etc., added similarly in a lighter ink, may have been entered by the same hand. The part name, title and incipit on the title page are written in a third hand. Cor I/II as well as some corrections in the string parts are in 'Hand 2'. The identification of the composer, "de Tartini" ( $v l$ princ) and "Tartini" ( $v l$ I), has been added by Joseph Terby.
D 50
No. 45
219
Mus.ms. 21635/68

Remarks: Manuscript parts of French provenance, written in a single hand. Title and incipit on the title page of the $v l$ princ by other hands; title in a hand similar to that of the title of No. 26 (apparently the same hand). "Tartini", on the title page of the vla, was added by Joseph Terby.
D 26
No. 48
220
Mus.ms. 21630

Remarks: Manuscript of French provenance inscribed "Sinfonia. A. 4." Parts in a single hand. This concerto a cinque was by mistake copied as a sinfonia a quattro.
D 24
No. 50
221
Mus.ms. 21635/23

Remarks: Manuscript of French provenance. The orchestra parts, strings and horns, as well as the title, part name (Violino Principale) and incipit on the title page, are in 'Hand 2'. The vl princ is in a different hand; at the end of all the movements there is a monogram denoting the copyist: "L." The part bears the number 17 ("n. ${ }^{\circ} \mid 17$ ") at the beginning. After the end of movt 3 a passage of 30 measures (a Capriccio, untitled) has been added in an old musician's hand; a second passage is apparently by Pagin.

D 119

${ }^{1}$ No. 69

Mus.ms. 21635/133

Remarks: Score copied by 'Berkeley A'. Large portions of the manuscript are illegible because of ink corro-

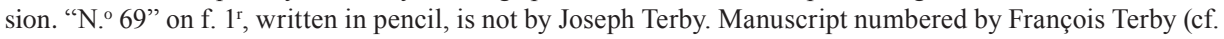
${ }^{3}$ No. 69$)$ - or by a different hand in 1879 , when the collection was sold?
D 119
${ }^{2}$ No. 69
223
Mus.ms. 21635/133

Remarks: Manuscript parts written in a French hand; title and incipit on the title page by different hand(s). $V l I$ and $v l$ II are exchanged in the solo sections. On a loose folio, a "Capricio" for the third movt, probably an autograph by Pagin, is attached to the manuscript.
D 119
${ }^{3}$ No. 69
Mus.ms. 21635/134

Remarks: Parts dated "Lovani | 1849." The copy was probably made by François Terby from the score by 'Berkeley A' ('No. 69). The numbering ("N. ${ }^{\circ} 69$ ") is in the copyist's hand.
D 106
${ }^{1}$ No. 71
224
Mus.ms. 21635/119

Remarks: Paduan manuscript. All parts are written by 'Berkeley D' (Bernardino de Zotti, $† 1777)$. The copy was made from a score, as indicated by a correction in $v l I I$ (movt 1).

\section{$\begin{array}{llll}\text { D } 106 & { }^{2} \text { No. } 71 & - & \text { Mus.ms. 21635/119 }\end{array}$}

Remarks: Score from the 19th century. This copy was made by Joseph Terby from the parts of 'Berkeley D' ( ${ }^{1}$ No. 71 ); movements 1 and 3 are incomplete (some folios are missing).
D 66
No. 72
Mus.ms. 21635/88

Remarks: Parts dated "Louvain. | 1850." The copy was probably made by François Terby; the numbering ("N. ${ }^{\circ} 72$ ") is in the hand of the copyist. 
D $110 \quad$ No. $74 \quad 226 \quad$ Mus.ms. 21635/116

Remarks: Manuscript parts from the 19th century. Copy made by Joseph Terby.

D 53 No. $75 \quad 228 \quad$ Mus.ms. 21635/65

Remarks: Manuscript of French provenance. The $v l$ princ is copied by 'Hand 1', the rest of the parts and the incipit on the title page are in 'Hand 3'. Title probably in 'Hand 1'. A correction in $v l$ II (movt 3) indicates that the copy was made from a score.

D $84 \quad$ No. $76 \quad 229 \quad$ Mus.ms. 21635/96

Remarks: Manuscript parts from the 19th century. Copy made by Joseph Terby.

D $11 \quad$ No. $78 \quad 230 \quad$ Mus.ms. 21635/4

Remarks: Manuscript of French provenance. Vl princ, vl I, vla are in 'Hand 1'. The other parts, $v l$ II and $b$, were copied by 'Hand 3'.

D $31 \quad$ No. $79 \quad 231 \quad$ Mus.ms. 21635/38

Remarks: Manuscript of French provenance. Almost all the parts are in 'Hand 1'; Violetta and the incipit on the title page are in 'Hand 3'.

D 122 No. $87 \quad 232 \quad$ Mus.ms. 21635/130

Remarks: Manuscript parts of French provenance. The incipit on the title page and the $v l$ princ are in a single hand (probably the same as the second hand of No. 19; 'Hand 3'?). The remaining parts were copied in a different hand.
D 36
${ }^{1}$ No. 95
238
Mus.ms. 21635/20

Remarks: Score copied by 'Berkeley A'. "95." is written in the upper left-hand corner of the title page, apparently in an old French hand.
D 36
${ }^{2}$ No. 95
233
Mus.ms. 21635/20

Remarks: Parts dated “(Louvain, 27 Août 1850.)." The copy was made by Joseph Terby from the score of 'Berkeley A' ('No. 95).
D 37
${ }^{1}$ No. 96
239
Mus.ms. 21635/32

Remarks: Score copied by 'Berkeley A'. " $\underline{96}$." is written in the upper left-hand corner of the title page, apparently in an old French hand. For the vl princ, there is an embellished version of the second movt, an autograph of Tartini, attached to the score.
D 37
${ }^{2}$ No. 96
234
Mus.ms. 21635/32

Remarks: Parts dated "Louvain, ce 30 Août 1850." The copy was made by Joseph Terby from the score of 'Berkeley A' ('No. 96).
D 35
${ }^{1}$ No. 97
240
Mus.ms. 21635/28

Remarks: Score copied by 'Berkeley A'. "97." "is written in the upper left-hand corner of the title page, apparently in an old French hand.
D 35
${ }^{2}$ No. 97
235
Mus.ms. 21635/28

Remarks: Parts dated “Louvain, 31 Aout 1850.” The copy was made by Joseph Terby from the score of 'Berkeley A' ('No. 97).
D 43
236
Mus.ms. 21635/54

Remarks: Manuscript parts apparently from the Flemish area. Title and $v l$ princ are in one hand; the other parts are copied by a second hand; incipit on the title page in a third hand. Clarifications of corrected notes: "d" (4x); "re" (1x); "ut", cropped. 
Appendix 2

\author{
CATALOGUE \\ DE LA BELLE COLLEGTION DE \\ VIOLONS ITALLENS, \\ WREXYMS DA TOURTM, \\ MUSIQUE DE CHAMBRE ET MANUSCRITS PRÉCIEUX \\ des grands maítres anciens et modernes, \\ DÉLAISSÉE PAR FEU
}

\title{
Mr JOSEPH TERBY,
}

ancien $1^{r}$ violon-solo

du Théâtre impérial Italien de Paris et maitre de chapelle

de l'église de St-Pierre à Louvain ;

dont la vente publique aura lieu en cette ville,

\section{le Jeudi 17 Juillet 1879,}

A $2 \%$ HEURES PRÉCISES,

Rue Graenendonck, No 1.

Figure 1. Title page of the sale catalogue of Joseph Terby's collection. Reproduced courtesy of the Sibley Music Library, Eastman School of Music, University of Rochester. 


$$
-15-
$$

Manuscrits des Concertos, pour Violon principal, avec accompagnement de 3 ou 4 parties, par G. Tartini.

La plupart de ces Concertos sont inédits (1).

\begin{tabular}{|c|c|c|c|c|c|c|}
\hline \multicolumn{2}{|c|}{$\begin{array}{l}\text { No du } \\
\text { Catalogue. } \\
201 \text { Concerto, }\end{array}$} & \multirow{2}{*}{$\overline{-}$} & \multicolumn{4}{|c|}{ 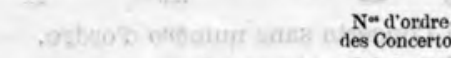 } \\
\hline 202 & - & & - & - & & 7. \\
\hline $20 \overline{-}$ & - & - & - & - & & 8. \\
\hline 204 & - & - & - & - & & 8 bis. \\
\hline 203 & - & - & - & - & & 10. \\
\hline 206 & - & - & - & - & & 19. \\
\hline 207 & - & - & - & - & & 19bis. \\
\hline 208 & - & - & - & - & 1 & 20 \\
\hline 209 & - & - & - & - & & 25. \\
\hline 210 & - & - & - & - & & 26. \\
\hline 211 & - & - & - & - & bitst & 29. \\
\hline 212 & - & - & - & - & & 50. \\
\hline 215 & - & - & - & - & & 50 bis. \\
\hline 214 & - & - & - & - & & 52. \\
\hline 215 & - & - & - &. & & 54. \\
\hline 216 & - & - & - & - & c. & 41. \\
\hline 217 & - & - & - & aty - & as: & 42. \\
\hline 218 & - & - & - & - & & 45. \\
\hline 219 & - & - & - & - & & 45bis. \\
\hline 220 & - & - & - & - & & 48. \\
\hline 221 & - & - & - & - & & so. \\
\hline 222 & - & - & - & tinut & 9 isit & 69. \\
\hline 223 & - & - & - & - & y ab. & 69bis. \\
\hline 224 & - & - & - & $-\quad-$ & - & 71. \\
\hline 225 & - & - & - & $-\quad-$ & - & 72. \\
\hline 226 & - & - & - & $-\quad-$ & - & 74. \\
\hline 227 & - & - & - & - & & 75. \\
\hline 228 & - & - & - & - & - & 7 bbis. \\
\hline 229 & - & - & - & $t^{2}-$ & - & 76. \\
\hline 250 & - & - & - & - & - & 78. \\
\hline 251 & - & - & - & $-\quad-$ & - & 79. \\
\hline 252 & - & - & - & $-\quad-$ & - & 87. \\
\hline
\end{tabular}

(1) Tartini les légua à son élève favori Pagin et M. Terby eut la bonne fortune de les acquérir après le décès de l'un des descendants de ce dernier.

Figure 2. The Tartini concertos from Joseph Terby's collection listed in the sale catalogue on pp. 13-14. Reproduced courtesy of the Sibley Music Library, Eastman School of Music, University of Rochester. 


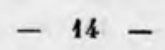

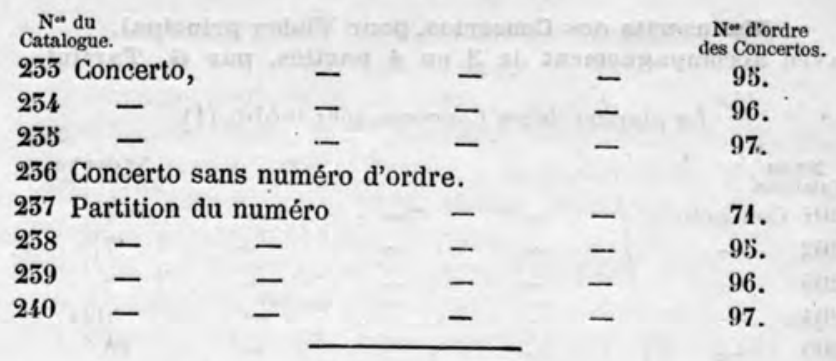

\section{Manuscrits.}

211 Concerto par Pergolèse.

212 Concerto par Lahoussaie.

2452 Concertos par Touchemolin.

2142 Concertos par Gaspar Fritz.

243 paquet de hasard.

\section{Instruments.}

1 Un Violon de grand patron attribué à Guarnérius.

2 Un Mathias Albani, fecit in Tirol. Bulsani, anno 1718.

3 Un Violon d'Antonio Zanotti.

1 Un Violoncelle.

5) Une belle Guitare neuve.

6 Les Archets de Tourte et d'autres bons maitres se vendront ici en détail.

A Archet de Tourte pour Violon.

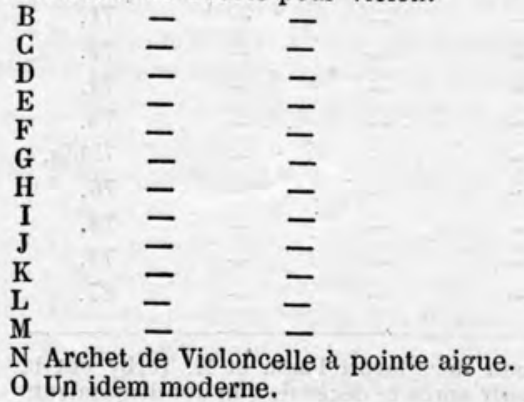




\section{Documents}

Staatsbibliothek zu Berlin - Preußischer Kulturbesitz: Musikabteilung, Accession. 1917-1925, 1921, 259-262.

\section{Online Manuscript Sources}

Pagin, Pierre. Capricci \& Cadenze: RISM Online Catalogue, D-B, Mus.ms.autogr. Pagin, P. 1 M, 'Read online' (or: http://resolver.staatsbibliothek-berlin.de, Mus.ms.autogr. Pagin, P. $1 \mathrm{M}$ ).

___ - Trio sonata: RISM Online Catalogue, D-B, Mus.ms.autogr. Pagin, P. 2 M, 'Read online' (or: http://resolver.staatsbibliothek-berlin.de, Mus.ms.autogr. Pagin, P. 2 M).

Tartini, Giuseppe. Concerto D 26: RISM Online Catalogue, D-B, Mus.ms. 21630, 'Read online' (or: http://resolver.staatsbibliothek-berlin.de, Mus.ms. 21630).

_—_ Concerto D 119: RISM Online Catalogue, D-B, Mus.ms. 21635/133, 'Read online' (or: http://resolver.staatsbibliothek-berlin.de, Mus.ms. 21635/133); 2 mss., 1 Capriccio by Pagin.

Thematische Verzeichnisse der Konzerte und Sonaten Giuseppe Tartinis, http://resolver. staatsbibliothek-berlin.de, Mus.ms.theor. Kat. 805.

\section{Bibliography}

Bachmann, Alberto. Les grands violonistes du passé. Paris: Librairie Fischbacher, 1913. Brainard, Paul. “Die Violinsonaten Giuseppe Tartinis.” PhD diss., Universität zu Göttingen, 1959.

___ L L L sonate per violino di Giuseppe Tartini: catalogo tematico. Padova: Accademia Tartiniana; Milano: Carisch, 1975.

Brook, Barry S. Thematic Catalogues in Music: An Annotated Bibliography. Hillsdale, New York: Pendragon Press, 1972.

“CATALOGUE | DE LA BELLE COLLECTION DE | VIOLONS ITALIENS, | ARCHETS DE TOURTE, | MUSIQUE DE CHAMBRE ET MANUSCRITS PRÉCIEUX | des grands maîtres anciens et modernes, | DÉLAISSÉE PAR FEU | M ${ }^{\mathrm{r}}$ JOSEPH TERBY [...].” Louvain: Typ. Charles Fonteyn, 1879.

Churchill, William A. Watermarks in Paper in Holland, England, France, etc., in the XVII and XVIII Centuries and Their Interconnection. Amsterdam: Menno Hertzberger \& Co., 1935.

Cooper, Jeffrey. "La Houssaye, Pierre-Nicolas.” In The New Grove Dictionary of Music and Musicians, 2nd edn, edited by Stanley Sadie, 14: 117-118. London: Macmillan, 2001.

Cousin, Jules. Le Comte de Clermont, sa cour et ses maîtresses. Lettres familières, recherches et documents inédits, vol. 2. Paris: Académie de Bibliophiles, 1867 (digitized by the Bayerische Staatsbibliothek). 
Dounias, Minos. Die Violinkonzerte Giuseppe Tartinis als Ausdruck einer Künstlerpersönlichkeit und einer Kulturepoche. Wolfenbüttel, Berlin: Georg Kallmeyer Verlag, 1935.

Duckles, Vincent; Elmer, Minnie and Petrobelli, Pierluigi. Thematic Catalog of a Manuscript Collection of Eighteenth-Century Italian Instrumental Music. Berkeley and Los Angeles: University of California Press, 1963.

Fay, Laurel and Barbieri, Patrizio. "Pagin, André-Noël." In The New Grove Dictionary of Music and Musicians, 2nd edn, edited by Stanley Sadie, 18: 897. London: Macmillan, 2001.

Fétis, François-Joseph. “Robberechts, André.” In Biographie universelle des musiciens et bibliographie générale de la musique, 2nd edn, VII: 276. Paris: Librairie de Firmin Didot Frères, Fils et C $C^{\text {ie }}, 1864$ ( ${ }^{2} 1867$ digitized by the Bibliothèque nationale de France). Gaudriault, Raymond. Filigranes et autres caractéristiques des papiers fabriqués en France aux XVII et XVIII ${ }^{e}$ siècles. Paris: CNRS Éditions / J. Telford, 1995.

Huybens, Gilbert. "Het Muziekconservatorium te Leuven (1835-1985)." Het stedelijk kunstonderwijs te Leuven, edited by Myriam Bols, Gilbert Huybens and Luc Verpoest, 95-138. Leuven: Stedelijke Academie voor Schone Kunsten, 1985.

Huybens, Gilbert and Robberechts, Geert. Frascati. Een kroniek van het muziekleven te Leuven in de 19de eeuw. Leuven: Peeters, 2010.

Laujon, Pierre. Euvres choisies, vol. 4. Paris: Patris et $C^{\text {ie }}, 1811$ (digitized by the Bibliothèque nationale de France).

Massip, Catherine. "Les filigranes: utilisation, lecture et reproduction." Fontes artes musicae 28 (1981): 87-93.

Pougin, Arthur. “Terby, Joseph.” In Biographie universelle des musiciens et bibliographie générale de la musique, 2nd edn, edited by François-Joseph Fétis, Supplément et complément, edited by M. Arthur Pougin, II: 568-569. Paris: Librairie de FirminDidot et $\mathrm{C}^{\mathrm{ie}}, 1880$ (digitized by the Bibliothèque nationale de France).

___ L L L Violon. Les Violonistes et la Musique de Violon du XVIe au XVIIIe siècle. Paris: Librairie Fischbacher, 1924 (digitized by the Bibliothèque nationale de France). Roquet, Flavie. “Terby, François-Pierre.” In Vlaamse componisten geboren na 1800, 673. Roeselare: Roularta Books, 2007.

____ “_Terby, Toussaint Joseph.” In Vlaamse componisten geboren na 1800, 673. Roeselare: Roularta Books, 2007.

SL/(Wirsta, Aristide). "Pagin, André-Noël.” In Die Musik in Geschichte und Gegenwart, 2nd edn, edited by Ludwig Finscher, Personenteil, 12: coll. 1555-1556. Kassel: Bärenreiter; Stuttgart: Metzler, 2004.

Tartini, Giuseppe. La raccolta di sonate autografe per violino. Manoscritto 1888 Fasc. 1 nell'Archivio Musicale della Veneranda Arca del Santo in Padova. Facsimile of the original, "Introduction" by Paul Brainard. Edizioni dell'Accademia Tartiniana. Milan: Casa Editrice Carisch, 1976.

Tebaldini, Giovanni. L’Archivio Musicale della Cappella Antoniana in Padova. Illustrazione storica-critica con cinque Eliotipie. Padua: Tipografia e Libreria Antoniana, 1895.

Voorn, Henk. "De papiermolens in de provincie Noord-Holland." De geschiedenis der Nederlandse papierindustrie, 1. Haarlem: De Papierwereld, 1960. 
Wilcox, Beverly. "The Hissing of Jean-Pierre Pagin: Diderot's Violinist Meets the Cabal at the Concert Spirituel.” In Studies in Eighteenth-Century Culture, vol. 40, edited by Downing A. Thomas and Lisa Cody, 103-132. Baltimore and London: The John Hopkins University Press, 2011.

\title{
ZBIRKA KONCERTOV GIUSEPPA TARTINIJA V OKVIRU PRUSKE KULTURNE DEDIŠČINE V BERLINSKI DRŽAVNI KNJǏ̌NICI
}

\author{
Povzetek
}

Tartinijevi koncerti, ki jih hrani Staatsbibliothek zu Berlin - Preußischer Kulturbesitz, so nekoč pripadali večji zbirki, ki jo je v 19. stoletju ustvaril v Leuvenu rojeni violinist, dirigent in skladatelj Joseph Terby mlajši (1801-1879). Iz prodajnega kataloga njegove zbirke izvemo, da je Terby 34 let živel v Parizu (1825-ok. 1859/60). Njegovo dolgotrajno bivanje v enem od najpomembnejših evropskih glasbenih središč mu je omogočilo nakupe številnih glasbenih rokopisov, tiskov ter glasbil.

Tartinijevi koncerti nedvomno sodijo med najdragocenejše rokopise njegove zbirke. Ohranilo se je 32 koncertov v 38 rokopisih, pet pa se jih je izgubilo. Dvanajst rokopisov izvira iz beneške pokrajine (morda vsi iz Padove, deloma gre za avtografe; štirje rokopisi vsebujejo tudi parte francoskega izvora). 17 rokopisov je francoskih in eden je deloma flamski. Vsi so iz 18. stoletja. Osem oziroma šest kopij je izdelal Joseph Terby sam, dve morda njegov brat François okoli sredine 19. stoletja. Kot nam pove prodajni katalog iz leta 1879, je imel rokopise pred Terbyjem v lasti francoski violinist Pierre Pagin, Tartinijev najljubši učenec. Pagin se je v mladosti pri maestru učil v Padovi (okoli 1739/40). Nekatere od rokopisov italijanskega in francoskega izvora bi lahko povezali s Paginom, vendar je zaradi manjkajočih podatkov nemogoče natančno določiti, koliko Tartinijevih rokopisov je imel Pagin, a vsekakor je jasno, da prav njegovi rokopisi tvorijo večji del poznejše Terbyjeve zbirke.

Sedem tematskih kazal Tartinijevih koncertov in sonat italijanskega (morda padovanskega), francoskega in belgijskega izvora iz 18. oziroma 19. stoletja bi skoraj vsi lahko bili iz Terbyjeve zbirke (dva sta zapisana z njegovo pisavo). Eden izmed teh popisov je bil verjetno izdelan šele potem, ko je bila Terbyjeva zbirka že prodana.

Rokopisi Tartinijevih koncertov iz Terbyjeve zbirke so na veliko srečo raziskovalcev skoraj vsi v celoti ohranjeni, saj so jih v 18. in 19. stoletju uporabljali predvsem glasbeniki. Kaj se je z rokopisi dogajalo med letom 1879, ko je bila zbirka v Leuvnu prodana, in letom 1921, ko jih je predhodnica Pruske državne knjižnice odkupila od berlinskega antikvarja Lea Liepmannssohna, pa ni znano. 